\title{
Lateral flow (immuno)assay: its strengths, weaknesses, opportunities and threats. A literature survey
}

\author{
Geertruida A. Posthuma-Trumpie • Jakob Korf • \\ Aart van Amerongen
}

Received: 21 May 2008 /Revised: 1 July 2008 / Accepted: 3 July 2008 / Published online: 13 August 2008

(C) The Author(s) 2008

\begin{abstract}
Lateral flow (immuno)assays are currently used for qualitative, semiquantitative and to some extent quantitative monitoring in resource-poor or non-laboratory environments. Applications include tests on pathogens, drugs, hormones and metabolites in biomedical, phytosanitary, veterinary, feed/food and environmental settings. We describe principles of current formats, applications, limitations and perspectives for quantitative monitoring. We illustrate the potentials and limitations of analysis with lateral flow (immuno)assays using a literature survey and a SWOT analysis (acronym for "strengths, weaknesses, opportunities, threats"). Articles referred to in this survey were searched for on MEDLINE, Scopus and in references of reviewed papers. Search terms included "immunochromatography", "sol particle immunoassay", "lateral flow immunoassay" and "dipstick assay".
\end{abstract}

Keywords Biomonitoring Clinical chemistry .

Food safety · Forensics · Lateral flow assay · Phytopathology · Veterinary

G. A. Posthuma-Trumpie $\cdot$ J. Korf

Department of Psychiatry,

University Medical Centre Groningen (UMCG),

University of Groningen,

Hanzeplein 1, P.O. Box 30.001, 9700 RB Groningen,

The Netherlands

A. van Amerongen $(\square)$

Agrotechnology and Food Sciences Group,

Wageningen University and Research Centre,

Bornsesteeg 59, P.O. Box 17, 6700 AA Wageningen,

The Netherlands

e-mail: aart.vanamerongen@wur.nl

\section{Introduction}

This study reports on the lateral flow (immuno)assay/ immunochromatography technique. Originally the technique was called "sol particle immunoassay" (SPIA) [1]. Lateral flow assays (LFAs), i.e. prefabricated strips of a carrier material containing dry reagents that are activated by applying the fluid sample, are important for diagnostic purposes, e.g. to ascertain pregnancy, failure of internal organs (e.g. heart attack, renal failure or diabetes), infection or contamination with specific pathogens including biowarfare agents, presence of toxic compounds in food, feed or the environment and abuse of (illicit) drugs. These assays are often incorrectly referred to as "dipsticks". Real dipstick assays are based on the immunoblotting principle and do not rely on lateral fluid flow through a membrane. In this survey lateral flow (immuno)assays are evaluated and, therefore, dipsticks that are lateral flow assays will be named LFAs. They are especially designed for single use at point of care/need, i.e. outside the laboratory. Applications are often designed where an on/off signal is sufficient. The best-known application is the pregnancy test $[1,2]$. Results usually come within 10-20 min. The current generation of LFAs has high sensitivity, selectivity and ease of use. In most cases sensitivity and selectivity are achieved by combining miniaturised thin-layer chromatography, the use of analyte-specific antibodies or DNA/RNA specific sequences, and by labelling the analyte or the recognition element.

The assay format in lateral flow immunoassay (LFIA) is comparable to that in enzyme immunoassay, although it does not replace that assay format. In fact, in the first reports on LFIAs use of the same components as in enzyme immunoassays was reported, immobilising the antibody on 
a chromatographic paper strip [3]. In doing so, advantage could be made of the chromatographic principle in addition to the immunological recognition system. The first labels were the enzymes used for enzyme immunoassays [4], but they were replaced soon by particulate labels [1]. Nowadays when a new method is presented for LFIAs, the performance of the new system is often referenced to the performance of enzyme immunoassays [5-8].

Lateral flow (immuno)assay is a technology that is currently widely applied [5-16]; however, to our knowledge no in-depth survey of recent literature is available. Here we present a survey of development reports presented in the scientific literature, mainly during the last decade, where a selection of those applications is mentioned that are real one-step dry reagent assays with coloured or luminescent response. A discussion on the strengths of, weaknesses of, opportunities for and threats to this technique is included as well.

\section{Principles of lateral flow (immuno)assays}

Essential in the current lateral flow (immuno)assay (LFA) formats is the movement of a liquid sample, or its extract containing the analyte of interest, along a strip of polymeric material thereby passing various zones where molecules have been attached that exert more or less specific interactions with the analyte. A typical LFA format consists of a surface layer to carry the sample from the sample application pad via the conjugate release pad along the strip encountering the detection zone up to the absorbent pad. The various elements will be discussed in more detail below; see also Fig. 1.

The membrane is often thin and fragile, so it is attached to a plastic or nylon basic layer to allow cutting and handling. In addition, robustness is achieved by housing the strips in a plastic holder, where only the sample application window and a reading window are exposed. Current membrane strips are produced from nitrocellulose, nylon, polyethersulfone, polyethylene or fused silica.

At one end of the strip a sample application pad is provided. The sample application pad is usually made of cellulose or cross-linked silica.

In close contact with the strip material and the sample application pad is the conjugate release pad, made of crosslinked silica. Labelled analyte or recognition element(s) (depending on the application) are dried on this pad and after addition of the sample, this material will interact with the fluid flow; specific interactions will be initiated here and will continue during the chromatographic process. Alternatively, the labelled analyte or recognition element(s) are dried in a reaction tube and the sample plus strip are added to the tube [6] (Fig. 2).

\section{Top view}

Application window Reading window
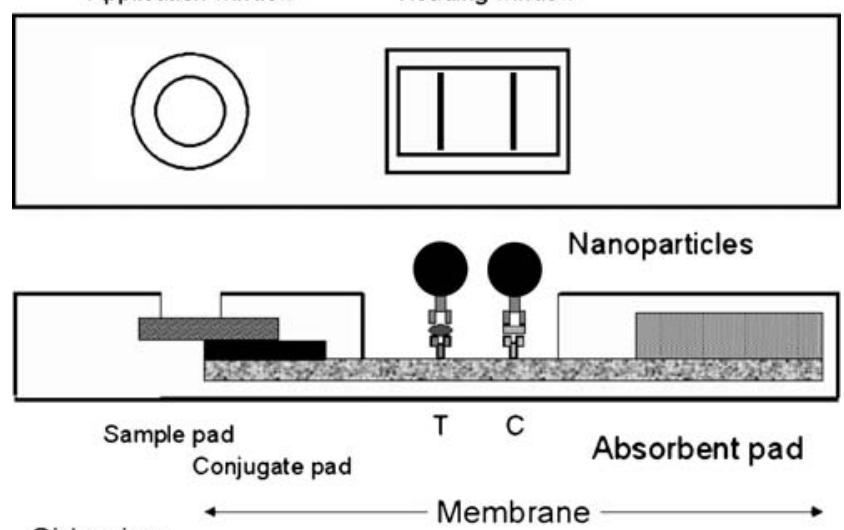

Side view

Fig. 1 Lateral flow immunoassay (LFIA) in sandwich format. Nanoparticle labelled antianalyte antibody 1 is dried at the conjugate release pad. Antianalyte antibody 2 is sprayed at the test line (T). Antispecies immunoglobulin $\mathrm{G}$ is sprayed at the control line $(C)$. Sample flows from the sample pad to the conjugate pad and into the membrane. Strips are mounted in a device for protection and easier handling

Labels are made of coloured or fluorescent nanoparticles with sizes of 15-800 nm, allowing an unobstructed flow through the membrane. They are often made of colloidal gold [1, 17-20] or latex [21], less often selenium [22], carbon [2, 23] or liposomes [24-29] are used. Latex nanoparticles are coloured [21] for optical detection. In liposomes coloured [21], fluorescent [27] or bioluminescent [29] dyes can be incorporated, allowing visualisation, and, when applicable, quantitation of the response. The newest labels include quantum dots [30] and upconverting phosphor technology [9, 31].

At least two lines are sprayed on the strip: a test line and a control line. At the test line the recognition of the sample analyte and the reporter will result in the required response.

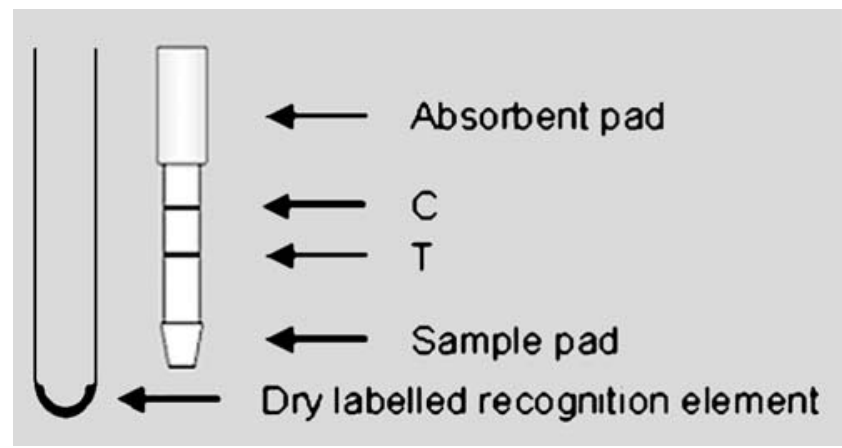

Fig. 2 Lateral flow (immuno)assay tube format; conjugate is dehydrated in a test tube. Tube and strip are stored in a sealed aluminium pouch and a desiccant. To run the test, sample (and buffer) are pipetted into the test tube, conjugate is dissolved and the strip is inserted. Response at the test line $(T)$ is dependent on the analyte concentration; response at the control line $(C)$ indicates a proper flow through the membrane 
A response at the control line confirms a proper flow of the liquid through the strip. More test lines can be applied allowing for multianalyte testing [32-36] or for semiquantitative evaluation of the response [37, 38].

The liquid moves because of the capillary force of the strip material, but to maintain a flow an absorbent pad is attached at the distal side of the strip. This absorbent pad will wick the liquid to the end of the strip, thus maintaining the flow.

When exclusively antibodies are used as recognition elements, the tests are called "lateral flow immunoassays" (LFIA). A combination of antigen-antibody interaction and specific tagged doubled-stranded amplicon (ds-amplicon) detection after PCR is also possible, and is called "nucleic acid lateral flow immunoassay" (NALFIA) [39, 40, 42, 69]. Specific nucleic acid hybridisation of amplicons with immobilised complementary probes is another option and is called "nucleic acid lateral flow assay" (NALF) [16, 41]. A selection of published LFA applications with the method applied and the sensitivity is presented in Tables 1, 2, 3 and 4; these were mainly published in the last decade. The examples have been grouped into four categories: infections (Table 1), metabolic disorders (Table 2), toxic compounds (Table 3), and miscellaneous applications (Table 4).

\section{Lateral flow immunoassay}

The LFIA set-up is designed to confirm the presence or absence of an (un)wanted compound; the analyte under consideration can be this compound, or a metabolic derivative. Antibodies to the analyte are used for recognition. Several formats have been described for LFIAs. These formats are chosen depending on the analyte. When the analyte is of low molecular mass and has only one epitope, i.e. a hapten, the format is restricted to the competitive design. Two layouts are possible: (1) antibody is sprayed at the test line, a mixture of sample analyte and labelled analyte is applied at the conjugate pad and the sample analyte and labelled analyte compete for binding sites on the antibody at the test line [68]; (2) an analyte-protein conjugate is sprayed at the test line, and a mixture of labelled antibody and sample analyte is applied at the conjugate pad, giving the sample analyte a head start for binding to the antibody [13]. The preferred layout is dependent on the particular application. In the competitive LFIA format the response is negatively correlated to the analyte concentration (i.e. more analyte present, less signal; no analyte gives the highest signal). A typical scheme of the competitive design and the response using option 2 is depicted in Fig. 3 (top).

For analytes with more than one epitope, the sandwich format is applicable. In this format the test line is prepared using one analyte-specific antibody. The conjugate release pad contains a second, labelled, antianalyte antibody. Analyte in the sample will bind during the initial chromatographic process to the second antibody. The free epitope can bind to the immobilised antibody at the test line [65]. The response is directly proportional to the amount of analyte in the sample; a scheme is depicted in Fig. 3 (bottom).

\section{Nucleic acid lateral flow (immuno)assay}

The NALFIA and the NALF set-ups are usually designed for testing the presence or absence of pathogens in food, feed or the environment. In the NALFIA set-up the analyte is an amplified double-stranded nucleic acid sequence (dsamplicon) specific of the organism using primers with two different tags; recognition of the analyte is done by binding to a tag-specific antibody [39, 40, 42, 69]. In a typical layout developed for the detection of pathogenic bacteria the nucleic acid was amplified using PCR with two tagged primers (Fig. 4a). A ds-amplicon was obtained with one strand labelled with biotin and the other strand labelled with, e.g., fluorescein isothiocyanate or digoxigenine. A solution of antibodies raised against the tag was sprayed at the test line. The biotin will bind to the avidin-labelled nanoparticles and the other tag will bind to the antitag antibody, resulting in the coloured signal [39]. The response is directly proportional to the amount of analyte.

For the NALF set-up several formats have been published: (1) nanoparticle-labelled reporter probe and biotin-labelled immobilised capture probe via avidin, single-stranded amplicon (ss-amplicon) hybridises with complementary reporter and capture probes (Fig. 4b) [16]; (2) nanoparticle-labelled reporter probe and bovine serum albumin labelled capture probe, immobilised through passive adsorption, ss-amplicon hybridises with complementary reporter and capture probes (Fig. 4c) [70]; (3) nanoparticle-labelled reporter probe; capture probe is immobilised at the test line through passive adsorption, ss-amplicon hybridises with complementary reporter and capture probes (Fig. 4d) [70]. The response is directly proportional to the amount of analyte [16].

Critical parameters and sensitivity of the assay

\section{Membrane material}

The membrane used as strip material is probably the single most important part of the test system. Most often the strip material is made of nitrocellulose $[12,19,23,33,46,58$, 63, 71, 72], available from Whatman, Pierce, Advanced Microdevices (India) or Millipore. Several other polymeric materials are also available, e.g. nylon [73] (Millipore, Pall Biosciences), polyethersulfone [15, 16] (Pall Biosciences or Nalgene-Nunc), polyethylene [51] (Porex) or fused silica 
Table 1 Overview of lateral flow (immuno)assays: detection of infectious agents

\begin{tabular}{|c|c|c|c|c|}
\hline Analyte & Method & Application & Sensitivity $^{\mathrm{a}}$ & References \\
\hline $\begin{array}{l}\text { Specific RNA after isothermal } \\
\text { amplification }\end{array}$ & $\begin{array}{l}\text { Polystyrene dyed microsphere } \\
\text { labelled specific } \\
\text { oligonucleotide }\end{array}$ & $\begin{array}{l}\text { Detection of Bacillus } \\
\text { anthracis }\end{array}$ & 2 B. anthracis cells & {$[43]$} \\
\hline $\begin{array}{l}\text { PCR amplified product with } \\
\text { dA tail of } 23 \mathrm{~S} \text { ribosomal RNA }\end{array}$ & $\begin{array}{l}\text { Colloidal gold labelled } \\
\text { oligo dT strands }\end{array}$ & $\begin{array}{l}\text { Bacterial infections } \\
\text { in arthroplasty }\end{array}$ & 10 cells of $S$. aureus & {$[15]$} \\
\hline $\begin{array}{l}\text { Brucella-specific IgM } \\
\text { antibodies in serum }\end{array}$ & $\begin{array}{l}\text { Colloidal dye (palanyl red) } \\
\text { labelled monoclonal antihuman } \\
\text { IgM antibody }\end{array}$ & Brucellosis & $93 \%$ positives & {$[44]$} \\
\hline $\begin{array}{l}\text { Citrus tristeza virus in } \\
\text { extracts from leaves or fruits }\end{array}$ & $\begin{array}{l}\text { Colloidal gold labelled } \\
\text { primary antibody }\end{array}$ & Detection of virus infection & $\begin{array}{r}90 \% \text { (leaves) }^{\mathrm{a}} \\
97 \% \text { (fruits) }^{\mathrm{a}}\end{array}$ & {$[8]$} \\
\hline $\begin{array}{l}\text { Cryptosporidium species } \\
\text { oocytes in water }\end{array}$ & $\begin{array}{l}\text { Dye-entrapped and } \\
\text { oligonucleotide-labelled } \\
\text { liposomes }\end{array}$ & $\begin{array}{l}\text { Contamination of } \\
\text { Cryptosporidium }\end{array}$ & 1 oocyst in $10 \mu \mathrm{L}$ & [41] \\
\hline $\begin{array}{l}4 \text { dengue serotypes after } \\
\text { isothermal nucleic acid } \\
\text { based amplification in serum }\end{array}$ & $\begin{array}{l}\text { Dye-entrapped liposome } \\
\text { DNA probe }\end{array}$ & Detection of virus infection & $\begin{array}{l}50-50,000 \text { copies of } \\
\text { RNA molecules in } \\
\text { serum }\end{array}$ & {$[16]$} \\
\hline $\begin{array}{l}\text { Human or animal IgG } \\
\text { in mosquito bloodmeal }\end{array}$ & Dye-labelled anti-IgG antibodies & $\begin{array}{l}\text { IgG (human or chicken) to detect } \\
\text { different host sources of blood } \\
\text { meal in insects }\end{array}$ & $10 \mu \mathrm{g} \mathrm{L}^{-1}$ & {$[32]$} \\
\hline $\begin{array}{l}\text { Influenza } A \text {, influenza } B \text { and } \\
\text { respiratory syncytial virus }\end{array}$ & $\begin{array}{l}\text { Raman signature labelled } \\
\text { antigen measures Raman } \\
\text { scattering }\end{array}$ & $\begin{array}{l}\text { Multianalyte detection of influenza } \\
\text { A, influenza B and respiratory } \\
\text { syncytial virus }\end{array}$ & & {$[45]$} \\
\hline $\begin{array}{l}\text { Leptospira-specific IgM } \\
\text { in serum }\end{array}$ & $\begin{array}{l}\text { Colloidal dye labelled } \\
\text { monoclonal antihuman } \operatorname{IgM} \\
\text { antibody }\end{array}$ & Leptospirosis & $\begin{array}{l}87 \% \text { overall } \\
\text { sensitivity }\end{array}$ & [21] \\
\hline Rotavirus in bovine faeces & $\begin{array}{l}\text { Colloidal gold labelled primary } \\
\text { antibody }\end{array}$ & $\begin{array}{l}\text { Detection of Rotavirus } \\
\text { infection }\end{array}$ & $70 \%$ of positives & {$[17]$} \\
\hline $\begin{array}{l}\text { Satsuma dwarf virus in } \\
\text { fruit extracts }\end{array}$ & Colloidal gold labelled antibody & Detection of virus infections & & {$[18]$} \\
\hline $\begin{array}{l}\text { Antibody to Schistosoma } \\
\text { japonicum in serum }\end{array}$ & $\begin{array}{l}\text { Blue colloidal dye labelled egg } \\
\text { antigen }\end{array}$ & Schistosomiasis & $\begin{array}{l}97 \% \text { positives in } \\
\text { acute form; } \\
94 \% \text { in chronic }\end{array}$ & {$[46]$} \\
\hline $\begin{array}{l}\text { Schistosoma circulating } \\
\text { cathodic antigen in urine }\end{array}$ & $\begin{array}{l}\text { Colloidal carbon labelled } \\
\text { primary antibody }\end{array}$ & Schistosomiasis & $0.2 \mu \mathrm{g} \mathrm{L}^{-1}$ & {$[12]$} \\
\hline $\begin{array}{l}\text { Streptococcus pneumoniae } \\
\text { DNA in a complex matrix } \\
\text { (fish sperm) }\end{array}$ & $\begin{array}{l}\text { Upconverting phosphor-labelled } \\
\text { species-specific DNA sequence }\end{array}$ & $\begin{array}{l}\text { Streptococcus pneumoniae } \\
\text { infection }\end{array}$ & $\begin{array}{l}1 \mathrm{ng} \text { of } \text { AluI- } \\
\text { restricted } S \text {. } \\
\text { pneumonia DNA }\end{array}$ & [9] \\
\hline $\begin{array}{l}\text { Antibodies to Treponema } \\
\text { pallidum and hepatitis B } \\
\text { antigen in serum }\end{array}$ & $\begin{array}{l}\text { Colloidal gold and } \\
\text { oligonucleotide labelled } \\
\text { antibody }\end{array}$ & $\begin{array}{l}\text { Treponema pallidum; } \\
\text { hepatitis B infection }\end{array}$ & $\begin{array}{l}5 \mu \mathrm{g} \mathrm{L}^{-1} \text { hepatitis } \\
\mathrm{B} \text { antigen }\end{array}$ & {$[33]$} \\
\hline $\begin{array}{l}\text { Antibody to Trichinella in } \\
\text { swine serum }\end{array}$ & Colloidal gold labelled antigen & Trichinellosis & $100 \%$ of positives & [19] \\
\hline
\end{tabular}

$\operatorname{Ig} G$ immunogobulin $\mathrm{G}, \operatorname{Ig} M$ immunogobulin $\mathrm{M}$

a Percentage of positives compared to the "gold standard"

(Fusion5, Whatman), but these are used less often. A slight tendency to use polyethersulfone material was observed for the NALF format $[15,16]$. Important are not only the capillary forces of the carrier material, but also the ease of binding and immobilising proteins necessary for sequential selection, reaction and detection.

For nitrocellulose, various pore sizes are available, varying from 0.05 to about $12 \mu \mathrm{m}$. However, the pores are not randomly distributed because of the manufacturing process, and a better description of the strip material should be capillary flow time, i.e., the time for the fluid front to travel into the strip material and is expressed as seconds per centimetre. First of all, the pore size and the material are important for the transport of the label [74]. A second requirement is the speed with which the complex of the sample analyte and the label are transported through the 
Table 2 Overview of lateral flow (immuno)assays: detection of metabolic disorders

\begin{tabular}{|c|c|c|c|c|}
\hline Analyte & Method & Application & Detection limit & Reference \\
\hline $\begin{array}{l}\text { Albumin in serum/whole } \\
\text { blood }\end{array}$ & $\begin{array}{l}\text { Fluorescent dye labelled } \\
\text { antibody or fluorescent dye } \\
\text { labelled antigen }\end{array}$ & $\begin{array}{l}\text { Albumin as a biomarker } \\
\text { for diabetes }\end{array}$ & $12.2-60 \mathrm{~g} \mathrm{~L}^{-1}$ & [47] \\
\hline $\begin{array}{l}\text { High-sensitivity } \\
\text { C-reactive protein in } \\
\text { whole blood }\end{array}$ & $\begin{array}{l}\text { Fluorescent dye labelled } \\
\text { antibody }\end{array}$ & $\begin{array}{l}\text { C-reactive protein as a potential } \\
\text { risk predictor for future } \\
\text { cardiovascular diseases }\end{array}$ & $0.133 \mathrm{mg} \mathrm{L}^{-1}$ & [48] \\
\hline $\begin{array}{l}\text { C-reactive protein; heart- } \\
\text { type fatty acid binding } \\
\text { protein in plasma }\end{array}$ & $\begin{array}{l}\text { Colloidal gold labelled } \\
\text { primary antibody }\end{array}$ & $\begin{array}{l}\text { C-reactive protein and heart-type fatty } \\
\text { acid binding protein as biomarkers of } \\
\text { cardiovascular diseases }\end{array}$ & $\begin{array}{l}2 \mathrm{mg} \mathrm{L}{ }^{-1} \mathrm{C} \text {-reactive protein; } \\
5 \mu \mathrm{g} \mathrm{L}^{-1} \text { heart-type fatty } \\
\text { acid binding protein }\end{array}$ & [35] \\
\hline $\begin{array}{l}\text { Lipoprotein A in serum, } \\
\text { plasma or blood }\end{array}$ & Selenium-labelled antigen & $\begin{array}{l}\text { Lipoprotein A as biomarker } \\
\text { for atherosclerosis }\end{array}$ & $<40 \mathrm{mg} \mathrm{L}^{-1}$ lipoprotein $\mathrm{A}$ & [22] \\
\hline Albumin in urine & $\begin{array}{l}\text { Alkaline colour reaction to } \\
\text { tetrabromphenol blue }\end{array}$ & Nephropathy & $98 \% \mathrm{PPV}$ & [49] \\
\hline $\begin{array}{l}\text { Eosinophil protein } \mathrm{X} \text {; } \\
\text { neutrophil lipocalin in } \\
\text { whole blood }\end{array}$ & $\begin{array}{l}\mathrm{Eu}(\mathrm{III}) \text { chelate microparticles } \\
\text { conjugated to primary } \\
\text { antibody }\end{array}$ & $\begin{array}{l}\text { Point of care for neutrophil, } \\
\text { eosinophil and leucocyte counts }\end{array}$ & $\begin{array}{l}0.082 \mathrm{~g} \mathrm{~L}^{-1} \text { for eosinophil } \\
\text { protein } \mathrm{X} ; 0.05 \mathrm{~g} \mathrm{~L}^{-1} \text { for } \\
\text { neutrophil lipocalin }\end{array}$ & {$[50]$} \\
\hline $\begin{array}{l}\text { Free and total prostate- } \\
\text { specific antigen }\end{array}$ & $\begin{array}{l}\text { Gold-labelled secondary } \\
\text { antibody }\end{array}$ & $\begin{array}{l}\text { Screening on prostate-specific } \\
\text { antigen }\end{array}$ & $\begin{array}{l}1 \mu \mathrm{g} \mathrm{L}^{-1} \text { prostate-specific } \\
\text { antigen }\end{array}$ & [51] \\
\hline $\begin{array}{l}\text { Human serum albumin } \\
\text { in urine }\end{array}$ & $\begin{array}{l}\text { Colloidal gold labelled } \\
\text { primary antibody and biotin- } \\
\text { labelled primary antibody }\end{array}$ & $\begin{array}{l}\text { Detection of renal disease and } \\
\text { its progression }\end{array}$ & $30 \mathrm{mg} \mathrm{L}^{-1}$ & [38] \\
\hline $\begin{array}{l}\text { Total PAPP-A and } \\
\text { PAPP-A complexed with } \\
\text { proMBP }\end{array}$ & $\begin{array}{l}\text { Europium- or biotin-labelled } \\
\text { antibody }\end{array}$ & $\begin{array}{l}\text { PAPP-A as a biomarker for } \\
\text { acute coronary syndromes }\end{array}$ & $\begin{array}{l}0.18 \mathrm{mIU} \mathrm{L} \mathrm{L}^{-1} \text { for total } \\
\text { PAPP-A and } 0.23 \mathrm{mIU} \mathrm{L}^{-1} \\
\text { for PAPP-A/proMBP }\end{array}$ & [52] \\
\hline
\end{tabular}

$P P V$ Positive predictive value of indicated metabolic disorder, $P A P P-A$ pregnancy-associated plasma protein A, proMBP pro form of eosinophil major basic protein

membrane allowing optimal reaction time. These parameters are also important when the sample has a high viscosity or contains fat globules, e.g. milk.

Usually nitrocellulose material to prepare the strips can be stored at ambient temperature and humidity; however, at low humidity, handling of the material can be difficult owing to accumulation of static electricity.

For polyethylene, the pore size can be controlled precisely, and when there is need for such properties, i.e. better reproducibility during the assembly and consequently better reproducibility during the tests, using this strip material is an option [51]. It might be noted here that larger pore sizes will widen the test line, and the sensitivity of the test will decrease, because faint lines can be missed.

However, publications describing a comparison of the performance of different strip materials could not be found.

\section{Material of the sample pad}

The sample pad can be used to perform multiple tasks; the most important is the promotion and even distribution of the sample to the conjugate pad. The sample pad can also be impregnated with, e.g. proteins, detergents, viscosity enhancers and buffer salts to influence the flow rate of the sample. The aim of such additions can be to increase the sample viscosity, to increase the reaction time at the conjugate pad or even to chemically modify the sample for binding at the test line. The pores in the sample pad can be symmetrically, homogeneously or inhomogeneously distributed, or can be asymmetrically distributed, providing an initial filter to remove coarse material, e.g. whole cells. Asymmetrical pore size distribution can be obtained from, e.g., Pall Ahlstrom (Cytosep) [6, 47, 55], or from Advanced Microdevices (India) [63].

The material of the sample pad is often chosen in advance in accordance with the aim of the test and the properties of the sample. Optimisation is usually not reported.

\section{Material of the absorbent pad}

The primary function of the absorbent pad is to wick the fluid through the membrane. When an absorbent pad is used, the amount of sample can be increased, resulting in an increased sensitivity. Most often cellulose filters are used.

\section{Material and size of the label}

As material of the label nowadays colloidal gold is used most often $[1,5,7,10,15,18-20,33,34,51,53,54,57$, 
Table 3 Overview of lateral flow (immuno)assays: detection of toxic compounds

\begin{tabular}{|c|c|c|c|c|}
\hline Analyte & Method & Application & Detection limit & References \\
\hline $\begin{array}{l}\text { Aflatoxin } B_{1} \text { in pig feed } \\
\text { extracts }\end{array}$ & $\begin{array}{l}\text { Colloidal gold labelled primary } \\
\text { antibody }\end{array}$ & $\begin{array}{l}\text { Contamination with } \\
\text { aflatoxin } \mathrm{B}_{1}\end{array}$ & $2 \mu \mathrm{g} \mathrm{kg}^{-1}$ & [53] \\
\hline $\begin{array}{l}\text { Botulinum neurotoxin D } \\
\text { in horse faeces }\end{array}$ & $\begin{array}{l}\text { Colloidal gold labelled primary } \\
\text { antibody }\end{array}$ & $\begin{array}{l}\text { Screening on Botulinum } \\
\text { presence }\end{array}$ & $50 \mathrm{ng} \mathrm{L}^{-1}$ & {$[54]$} \\
\hline $\begin{array}{l}\text { Carbaryl and endosulfan } \\
\text { in extracts of cereals and } \\
\text { vegetables }\end{array}$ & $\begin{array}{l}\text { Colloidal gold or HRP labelled } \\
\text { primary antibody }\end{array}$ & $\begin{array}{l}\text { Pesticide residues of } \\
\text { carbaryl and endosulfan }\end{array}$ & $\begin{array}{l}100 \mu \mathrm{g} \mathrm{L}^{-1} \text { for carbaryl; } \\
10 \mu \mathrm{g} \mathrm{L}^{-1} \text { for endosulfan }\end{array}$ & {$[36]$} \\
\hline $\begin{array}{l}\text { (Dihydro)streptomycin in raw } \\
\text { milk }\end{array}$ & $\begin{array}{l}\text { Colloidal gold labelled primary } \\
\text { antibody }\end{array}$ & $\begin{array}{l}\text { Antibiotics residues of } \\
\text { (dihydro)streptomycin }\end{array}$ & $\begin{array}{l}25 \mu \mathrm{g} \mathrm{kg}^{-1} \text { for } \\
\text { streptomycin; } 50 \mu \mathrm{g} \mathrm{kg}^{-1} \\
\text { for dihydrostreptomycin }\end{array}$ & {$[55]$} \\
\hline $\begin{array}{l}\text { Fumonisin B1 in extracts of } \\
\text { cereals and peanuts }\end{array}$ & $\begin{array}{l}\text { Colloidal gold labelled primary } \\
\text { antibody }\end{array}$ & $\begin{array}{l}\text { Contamination with } \\
\text { mycotoxin fumonisin } \mathrm{B}_{1}\end{array}$ & $1.0 \mu \mathrm{g} \mathrm{L}^{-1}$ & {$[5]$} \\
\hline $\begin{array}{l}\text { Glycyrrhizic acid in extracts of } \\
\text { roots, leaves or stems of } \\
\text { liquorice plant samples }\end{array}$ & $\begin{array}{l}\text { Colloidal gold labelled primary } \\
\text { antibody }\end{array}$ & $\begin{array}{l}\text { Determination of } \\
\text { glycyrrhizic acid } \\
\text { concentration }\end{array}$ & $20-50 \mu \mathrm{g} \mathrm{L}^{-1}$ & {$[56]$} \\
\hline $\begin{array}{l}\text { Medroxy-progesterone acetate } \\
\text { in extractions of swine liver or } \\
\text { urine }\end{array}$ & $\begin{array}{l}\text { Colloidal gold labelled primary } \\
\text { antibody }\end{array}$ & Residue of analyte & $10 \mathrm{mg} \mathrm{kg}^{-1}$ & {$[57]$} \\
\hline Microcystin-LR in freshwater & $\begin{array}{l}\text { Biotin-fluorescein-labelled analyte } \\
\text { or antianalyte biotin-fluorescein- } \\
\text { labelled primary antibody }\end{array}$ & $\begin{array}{l}\text { Determination of } \\
\text { microcystin presence }\end{array}$ & $50 \mathrm{ng} \mathrm{L}^{-1}$ or $100 \mathrm{ng} \mathrm{L}^{-1}$ & {$[58]$} \\
\hline $\begin{array}{l}\text { Nicarbazin residues in poultry } \\
\text { feed }\end{array}$ & $\begin{array}{l}\text { Blue latex microsphere labelled } \\
\text { primary antibody }\end{array}$ & $\begin{array}{l}\text { Residue of pesticide } \\
\text { nicarbazin }\end{array}$ & $2 \mathrm{mg} \mathrm{kg}^{-1}$ & [59] \\
\hline Sulfadimidine in urine or milk & $\begin{array}{l}\text { Colloidal gold labelled primary } \\
\text { antibody }\end{array}$ & $\begin{array}{l}\text { Residue of antibiotic } \\
\text { Sulfadimidine }\end{array}$ & $\begin{array}{l}10 \mu \mathrm{g} \mathrm{L}^{-1} \text { in urine; } 10 \mu \mathrm{g} \\
\mathrm{L}^{-1} \text { in fresh bovine milk }\end{array}$ & {$[20]$} \\
\hline Sulfametazine in urine & $\begin{array}{l}\text { Colloidal carbon labelled secondary } \\
\text { antibody }\end{array}$ & $\begin{array}{l}\text { Residue of antibiotic } \\
\text { sulfametazine }\end{array}$ & $\begin{array}{l}6.3 \mu \mathrm{g} \mathrm{L}^{-1} \text { in diluted } \\
(1 / 10) \text { urine }\end{array}$ & [13] \\
\hline $\begin{array}{l}\text { Generic test on Sulfonamides } \\
\text { in eggs and chicken muscle }\end{array}$ & Colloidal gold labelled antibody & Residue of antibiotics & $10-40 \mu \mathrm{g} \mathrm{L}^{-1}$ & {$[10]$} \\
\hline $\begin{array}{l}\text { Verotoxigenic Escherichia coli } \\
\text { in raw milk, minced beef, } \\
\text { apple juice and salami }\end{array}$ & $\begin{array}{l}\text { Colloidal carbon labelled primary } \\
\text { antibody }\end{array}$ & $\begin{array}{l}\text { Single analyte and } \\
\text { multianalyte verotoxigenic } \\
\text { Escherichia coli detection }\end{array}$ & $100 \%$ positives $^{\mathrm{a}}$ & {$[11,60]$} \\
\hline
\end{tabular}

$H R P$ horseradish peroxidase

a Percentage of positives compared to the "gold standard"

$61,66,67,71,75-77]$. A runner-up is the use of coloured latex particles $[21,76,78]$. The use of other coloured nanoparticles was mentioned as well. Among those are carbon [2, 23] and selenium [22]. Chemiluminescent and fluorescent nanoparticles are used less often $[9,16,58$, 79]. An important requirement for the nanoparticle labels is their colloidal stability in solution. Among others, this can be achieved upon coating the binding proteins on the surface of the nanoparticle. Electrical charge can be generated by choosing the right conditions (i.e. buffer composition, buffer strength, $\mathrm{pH}$ ). A stable suspension ensures a uniform distribution of the conjugate when preparing the conjugate pad. The size of the gold nanoparticles can be controlled during manufacturing. Several publications report on a comparison of the size of the nanoparticles [68, 74, 77]. Better sensitivity using larger particles was observed; however, the stability of the colloid was diminished with particles over $40 \mathrm{~nm} \mathrm{[68].} \mathrm{This}$ problem was not mentioned in [77], where an optimum was found using gold nanoparticles of $80 \mathrm{~nm}$. Liposome colloids can be instable as well, so in a typical application, the liposomes were immobilised and the label ruptured the liposomes, releasing an electroactive compound in a concentration-dependent way [80].

As was the case for strip material, a comparison of sensitivities using different labels could not be found.

\section{Recognition element}

The sensitivity of the LFIA is to a large extent dependent on the affinity of the specific antibody. Specific antibodies (primary antibodies) can be labelled to provide a response; however, a high concentration of, often expensive, material is necessary. When secondary antispecies antibodies (often 
Table 4 Overview of lateral flow (immuno)assays: miscellaneous applications

\begin{tabular}{|c|c|c|c|c|}
\hline Analyte & Method & Application & Detection limit & References \\
\hline $\begin{array}{l}\text { Antianthrax } \\
\text { protective IgG in } \\
\text { serum or whole } \\
\text { blood }\end{array}$ & $\begin{array}{l}\text { Colloidal gold labelled } \\
\text { streptavidin with analyte }\end{array}$ & $\begin{array}{l}\text { Confirmation of previous infection or } \\
\text { vaccination }\end{array}$ & $\begin{array}{l}3 \mathrm{mg} \mathrm{L}{ }^{-1} \mathrm{IgG} \text { in serum; } \\
\sim 14 \mathrm{mg} \mathrm{L}^{-1} \text { IgG in whole } \\
\text { blood; } 100 \% \text { positives }^{\mathrm{a}}\end{array}$ & {$[61]$} \\
\hline $\begin{array}{l}\text { Bovine } \mathrm{IgG} \text { in dried } \\
\text { porcine plasma }\end{array}$ & $\begin{array}{l}\text { Colloidal gold labelled } \\
\text { primary antibody }\end{array}$ & $\begin{array}{l}\text { Bovine IgG as marker of plasma } \\
\text { contamination }\end{array}$ & $0.01 \% \mathrm{v} / \mathrm{v}$ & [62] \\
\hline $\begin{array}{l}\text { Cortisol in blood/ } \\
\text { serum }\end{array}$ & $\begin{array}{l}\text { Colloidal gold labelled } \\
\text { primary antibody }\end{array}$ & Quantitation of cortisol concentration & $3.5 \mu \mathrm{g} \mathrm{L}^{-1}$ in plasma & [63] \\
\hline $\begin{array}{l}\text { Fungal } \alpha \text {-amylase in } \\
\text { environmental } \\
\text { samples }\end{array}$ & $\begin{array}{l}\text { Colloidal carbon labelled } \\
\text { primary antibody }\end{array}$ & $\begin{array}{l}\text { Fungal } \alpha \text {-amylase contamination at } \\
\text { the workplace }\end{array}$ & $1-10 \mu \mathrm{g} \mathrm{L}^{-1}$ & {$[6,64]$} \\
\hline $\mathrm{hGC}$ in urine & $\begin{array}{l}\text { Colloidal carbon labelled } \\
\text { primary antibody }\end{array}$ & $\begin{array}{l}\text { Determination of presence of hCG } \\
\text { (pregnancy test) }\end{array}$ & $10 \mathrm{mIU} \mathrm{mL} \mathrm{mL}^{-1}$ & {$[65]$} \\
\hline hCG or TPSA & $\begin{array}{l}\text { Colloidal gold labelled } \\
\text { primary or secondary } \\
\text { antibody }\end{array}$ & $\begin{array}{l}\text { Determination of presence of hCG } \\
\text { (pregnancy test) or TPSA for } \\
\text { screening for prostate cancer }\end{array}$ & $\begin{array}{l}1 \mathrm{ng} \mathrm{L}{ }^{-1} \mathrm{hCG} \text { in urine; } 10 \mathrm{ng} \\
\mathrm{L}^{-1} \mathrm{hCG} \text { in serum; } 0.2 \mu \mathrm{g} \mathrm{L}^{-1} \\
\text { TPSA in serum }\end{array}$ & {$[66]$} \\
\hline $\begin{array}{l}\text { Oestrone sulphate in } \\
\text { mares' urine }\end{array}$ & $\begin{array}{l}\text { Uniformly blue dyed } \\
\text { polystyrene microsphere } \\
\text { labelled primary antibody }\end{array}$ & Confirmation of pregnancy & $5 \mu \mathrm{g} \mathrm{L}^{-1}$ & {$[14]$} \\
\hline $\begin{array}{l}\text { Progesterone in } \\
\text { bovine milk }\end{array}$ & $\begin{array}{l}\text { Colloidal gold labelled } \\
\text { analyte-ovalbumin conjugate }\end{array}$ & $\begin{array}{l}\text { Determination of the reproductive } \\
\text { status of dairy animals }\end{array}$ & $5 \mu \mathrm{g} \mathrm{L}^{-1}$ & {$[67]$} \\
\hline
\end{tabular}

$h G C$ human chorionic gonadotropin, TPSA total prostate-specific antigen

a Percentage of positives compared to the "gold standard"

less expensive) are labelled, the primary antibodies can be titrated for optimal response [13]. Moreover, the affinity of the primary antibodies might decrease upon conjugation to the label, diminishing the sensitivity. This phenomenon is comparable to immobilisation of an enzyme in a reactor, shown, e.g., in [81]. Steric hindrance might hamper the antigen-antibody interaction as well. The dependency of the affinity on labelling primary antibody cannot be predicted;

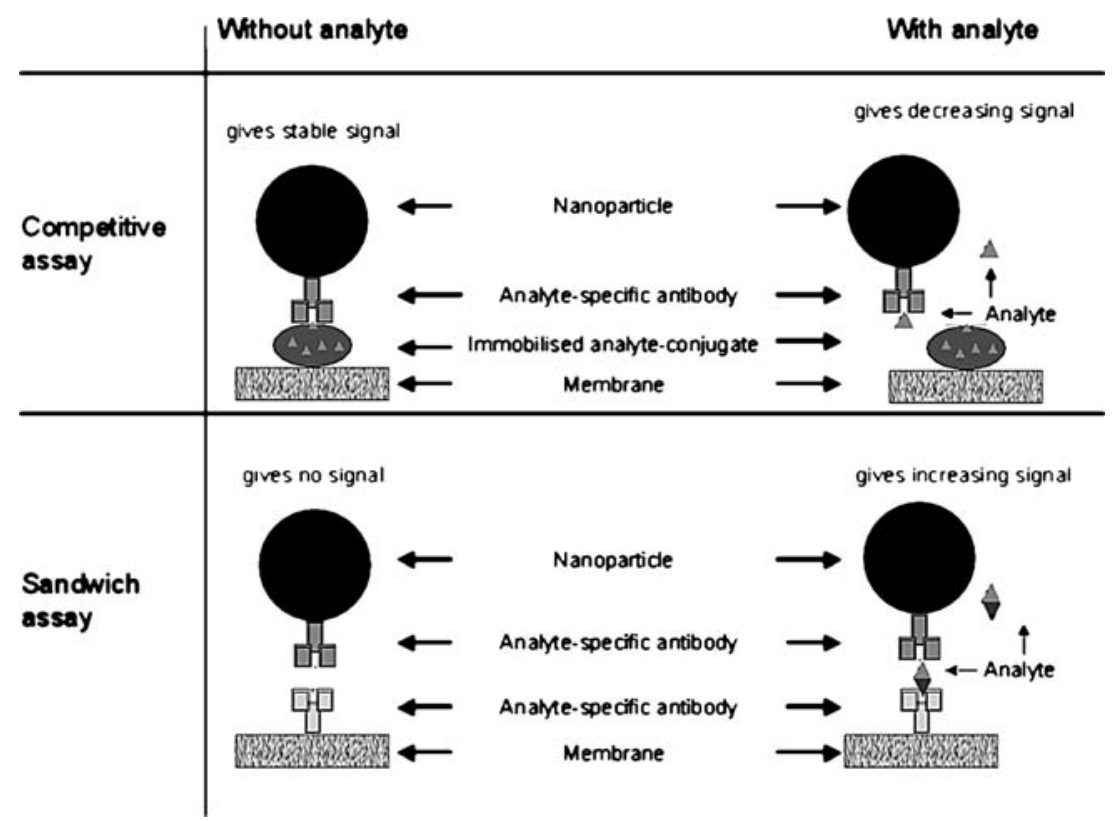

Fig. 3 Difference in layout and signal generation between competitive LFIA and sandwich LFIA. In the competitive format the response is negatively correlated to the amount of analyte in the sample (top).
In the sandwich format the response is directly proportional to the amount of analyte in the sample (bottom) 


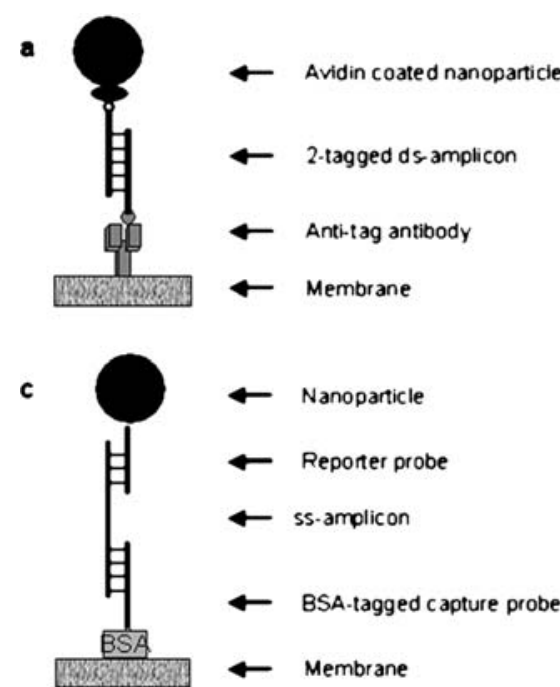

Fig. 4 A number of possible formats for nucleic acid lateral flow assays; detail at the test line (not to scale). a Nucleic acid lateral flow immunoassay test format: nanoparticle-labelled avidin is used as reporter and two tagged primers (e.g. biotin and fluorescein isothiocyanate, FITC) label the double-stranded amplicon ( $d s$-amplicon). Biotin binds to avidin; and anti-FITC antibody, sprayed at the test line, binds to FITC. b Nucleic acid lateral flow test format: nanoparticle-labelled reporter probe and biotin-labelled immobilised

however, comparison of labelling primary or secondary antibodies on the sensitivity of the assay could not be found.

For the nuclei acid assays, the availability of good primers during the amplification process is indispensable. In the NALFIA format the recognition is done by antibody tag-label interaction and the biotin-avidin reaction. In the NALF format complementary probes have to be hybridised to the amplicons. This hybridisation is often done before the chromatographic process. It might be noted here that hybridisation usually takes more time than antibody taglabel interaction, favouring NALFIA over NALF.

\section{Position of the test line}

The position of the test line is important for the performance of the assay. More interaction time is available when the test line is farther downstream from the sample application side of the strip. An optimum is usually obtained, as the speed of movement of the fluid decreases with distance.

\section{Optimisation}

Usually a first step in the development of the assay is the optimisation of the concentration of the label and the recognition element. The second step is the optimal position of the test line. Both are aimed at optimal sensitivity of the

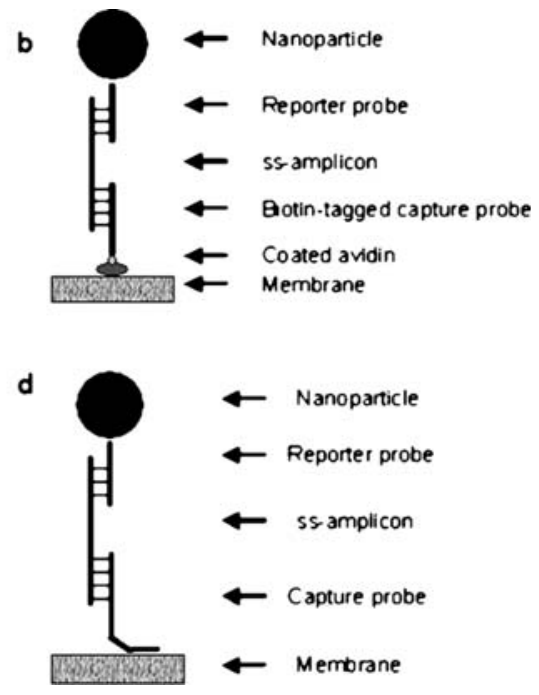

capture probe, single-stranded amplicon (ss-amplicon) hybridises with reporter and capture probes. c Nucleic acid lateral flow test format: nanoparticle-labelled reporter probe and bovine serum albumin labelled capture probe, immobilised through passive adsorption, ssamplicon hybridises with reporter and capture probes. d Nucleic acid lateral flow test format: nanoparticle-labelled reporter probe; capture probe is immobilised at the test line through passive adsorption, ssamplicon hybridises with reporter and capture probes

assay. Strip material, the label and the detection strategy are usually the personal choice of the research group developing the assay. However, often the development of a new test is aimed at circumventing existing patents.

\section{SWOT analysis}

A SWOT (acronym for "strengths, weaknesses, opportunities and threats") analysis of the lateral flow (immuno)assay format is discussed here. An overview of strengths and weaknesses, internal to the format, is given in Table 5. An overview of opportunities and threats, presented by the external environment, is given in Table 6.

\section{Strengths}

Many successful LFAs are mentioned and all are designed for use at point of care/need: the physician's examination room, emergency ward in general hospitals, tests on food or feed for toxic compounds, presence or absence of infectious diseases in medical or phytopathological settings or adulteration with undesirable components in food/feed industries. Also for tests related to biowarfare, law enforcement and forensics, this format is preferred regularly. However, regulatory bodies often require an independent test to be performed on samples that test positive. In this case LFA tests can be used for primary screening at point of care/need. 
Table 5 SWOT analysis of lateral flow assay: internal factors

\begin{tabular}{|c|c|}
\hline Strengths & Weaknesses \\
\hline One-step assay, no washing step necessary & One-step assay, no washing step possible \\
\hline Fast and low cost, low sample volume & Qualitative or semiquantitative results \\
\hline Reduced development time brings applications faster to the market & $\begin{array}{l}\text { Response is negatively correlated to concentration in competitive } \\
\text { format }\end{array}$ \\
\hline Simple test procedure & Imprecise sample volume reduces precision \\
\hline Applications at point of care/need & Restriction on total volume in test gives a limit on sensitivity \\
\hline Sensitive for proteins, haptens and nucleic acid amplicons & $\begin{array}{l}\text { In one-step format no possibility to enhance the response by enzyme } \\
\text { reaction }\end{array}$ \\
\hline Versatile format & $\begin{array}{l}\text { Good antibody preparation or hybridisation nucleic acid sequence } \\
\text { obligatory }\end{array}$ \\
\hline $\begin{array}{l}\text { Individual tests or sometimes array format for batchwise mid-throughput } \\
\text { screening }\end{array}$ & $\begin{array}{l}\text { Usually designed for individual tests, not for high-throughput } \\
\text { screening }\end{array}$ \\
\hline $\begin{array}{l}\text { Prolonged shelf life without the need to refrigerate, larger batches can be } \\
\text { prepared in advance }\end{array}$ & Obstruction of pores due to matrix components \\
\hline Qualitative (on/off) or semiquantitative result & Immunostrips usually not manufactured for the purpose \\
\hline Sample pretreatment is often not necessary when the sample is a fluid & Sample pretreatment is obligatory when the sample is not a fluid \\
\hline
\end{tabular}

Especially in third-world countries these tests are used for biomedical purposes, since there is no need to refrigerate the strips prepared. Moreover, visual interpretation of the results is often satisfactory. Owing to their extended shelf life, large batches can be prepared, diminishing the variation between batches.

LFAs are designed for disposable single use and no contamination with previously tested sample will occur.

\section{Weaknesses}

The weaknesses will be discussed in more detail and, if possible, improvements will be proposed, especially with respect to quantitative results.

LFAs are a one-step assay, no washing step is possible. Preblocking of the strips is not advisable. Nitrocellulose immunostrips are prepared with well-balanced hydrophobicity and wetting properties. Washing or pretest blocking will destroy these properties. However, in several publications preblocking the strips was mentioned [38, 68, 74].

Tests are developed aiming at on/off results. When a more semiquantitative result is required, simple evaluation by spraying a series of lines of capture reagent with increasing concentration (comparable to a bar code) is sometimes sufficient [37, 38]. A more extended format uses evaluation of the signal by a measuring device. This can be a simple hand-held reflectometer [24, 82, 83], but when a more precise evaluation is required, the signal can be digitised using a flatbed scanner or a CCD camera and dedicated software [23, 39, 65]; however, costs and analysis time will increase, although there is a trend in reduction of hardware costs due to miniaturisation. In contrast, using a reader diminishes subjective user interpretation, enables the storage of data and is often more sensitive than visual interpretation.

In the competitive format the response is negatively correlated to the concentration. Especially when it is used

Table 6 SWOT analysis of lateral flow assay: external factors

\begin{tabular}{ll}
\hline Opportunities & Threats \\
\hline $\begin{array}{l}\text { New applications at point of care/need } \\
\text { Application on other biomatrices: tears, saliva, sweat }\end{array}$ & $\begin{array}{l}\text { GC-MS or LC-MS in an automated format } \\
\text { Automated enzyme innunoassays }\end{array}$ \\
$\begin{array}{l}\text { Better reproducibility using automation of manufacturing, sample } \\
\text { and reagent addition, drying time and read-out of results }\end{array}$ & $\begin{array}{l}\text { Immunosensor formats (e.g. Biacore, grating coupler, total internal } \\
\text { Miniaturisation of the LFIA strips }\end{array}$ \\
$\begin{array}{l}\text { reflectance fluorescence, magneto-biosensor, Young interferometer sensor) } \\
\text { Sweeping of }\end{array}$ \\
$\begin{array}{l}\text { New applications carticle immunoassays (e.g. Luminex }{ }^{\circledR} \text { and related brands) } \\
\text { faster development }\end{array}$
\end{tabular}

GC-MS gas chromatography-mass spectrometry, LC-MS liquid chromatography-mass spectrometry, LFIA lateral flow immunoassay 
by untrained persons, this might cause ambiguities. Changing the format by using an "immunothreshold" can overcome this problem [63]. In this format two lines are sprayed on the immunostrip, line 1 is the analyte-protein conjugate and line 2 is the secondary antibody. Primary antibodies conjugated to colloidal nanoparticles are applied on the conjugate release pad. When no analyte is present in the sample, all antibodies will bind to the immobilised analyte at line 1; however, when analyte is present, primary antibodies will bind to line 1 and/or line 2 in an analyteconcentration-dependent way, and the intensity of the latter line is evaluated.

Tests are usually sold as kits, providing all the items necessary for performance of the test, such as a dropper for taking a fixed amount of sample. However, when an untrained user executes the test, accurate use of the dropper is not an easy task, resulting in test errors. Application of a better measuring device for sample addition will improve this part of the execution of the test. An option is to use an automatic dispenser; however, when the point of care/need is restricted to "in the field" this will not be easy, but for applications where the point of care/need is located in, e.g., a feed mill, in the physician's examination room or in the emergency ward of hospitals, sample addition with an automated sampling device will increase the accuracy and reproducibility of the test. It will depend on the purpose of the test whether this is necessary, taking into account that the investment costs will increase.

Inherent to the test format, the mounting device has a restricted volume, often limited to $100 \mu \mathrm{L}$; larger volumes, especially over $1 \mathrm{~mL}$, are precluded. Addition of several loads of sample will deteriorate the immunostrip, and will increase the assay time. The development and application of more sensitive tags is highly recommended here. To accommodate larger volumes a different assay format should be used, most probably not a one-step format.

Several attempts have been made to increase the signal by introducing an enzyme as the label [36, 84, 85] or electrochemical signal generation [86-88]. Silver enhancement of the response of the gold nanoparticles has been mentioned as well for sensitivity increase [89-91]. Apart from losing the "one-step" concept when using an enzyme, a biological element with limited stability is introduced; shelf life may decrease and handling becomes more complicated. The application of a silver enhancer also requires a second step. When an electrochemical transducer is used, investment costs might rise to undesirable levels. Approaches using other physical properties of the label include the localised surface plasmon resonance of the gold nanoparticles to increase the signal [66] and surfaceenhanced Raman scattering of gold or silver nanoparticles [45]. More sensitive chemiluminescent [50] or fluorescent $[24,47,48,92]$ labels may increase the sensitivity, but will increase the cost of the assay, because more sophisticated hardware and software are needed to read the signal. A typical approach that is used for signal enhancement and quantitation employs hexacyanoferrate(II)-loaded liposomes in combination with a melittin-labelled analyte analogue [80]. On the membrane, antianalyte antibody is immobilised in an antibody competition zone and hexacyanoferrate(II)-loaded liposomes are immobilised in a signal generation zone. At the capture zone, analyte and labelled analyte analogue compete for binding sites of the immobilised antibody. The amount of the melittin conjugate bound at the antibody site is inversely proportional to the concentration of the analyte in the sample. The unbound conjugate can migrate to the signal-generating zone where the immobilised loaded liposomes are lysed owing to the action of the melittin, releasing the hexacyanoferrate(II). The amount of the latter compound can be measured amperometrically and is directly proportional to the amount of analyte in the sample.

Raising a sensitive antibody with good selectivity is not always possible owing to the nature of the analyte under consideration. Selection of the antibody with the required properties is dependent on several factors that may not be compatible with one another. Furthermore, covalent attachment can decrease the affinity for the antigen. Often a compromise is the only option and consequently the performance of the test is restricted in one aspect or another. Selection of a good nucleotide sequence that enables rapid hybridisation in the NALF format can be very time-consuming and is often trial and error. Several authors reported on batchwise implementation of assays (multiple sample testing), in the microarray format [24, 39, 43] or simply by sticking several strips on a plastic backing [85]. There are also reports on combined testing of one sample on several analytes (multianalyte testing) [33, 34, $36,73,93]$. However, individual tests performed sequentially in high-throughput mode in an automated set-up, necessary for, e.g., automated progesterone tests in the milking parlour, are not mentioned.

Inherent to a rapid test, it is advantageous when sample pretreatment is not necessary. For applications using blood/ plasma/serum or extracts, special sample pad materials are available that filter cells and/or debris from obstructing the immunostrip. However, the sample has to be in the liquid state, and sample pretreatment is obligatory when solid samples, or dust particles in the atmosphere are analysed. Even when the sample is liquid, sample cleanup may be necessary. Also, when the analyte has a very low concentration, a preliminary concentration step is obligatory. In the nucleic acid lateral flow(immuno)assay set-up, an amplification step (nucleic acid based amplification, PCR) is often necessary. Often such protocols can be automated, but handling will be more complicated and assay time will 
increase. Still, LFAs can offer rapid results compared with traditional techniques [39, 41].

\section{Opportunities}

Opportunities are mainly related to off-laboratory applications. The success of the pregnancy test is the best-known example. Many tests are available nowadays for home testing; these are non-prescription tests that can be obtained at the pharmacy or through the Internet, however there is still an enormous potential left. Examples include testing in the consulting room of the general practitioner or in the emergency ward at the hospital, testing on drugs of abuse for law enforcement, absence of pathogenic organisms in food/feed, seed and seedlings, forensics and tests related to biowarfare, where fast results are of utmost importance.

The matrix of these tests is usually blood/serum/plasma or urine, (extracts of) the food or feed to be tested or extracts of soil or water for environmental issues. In biomedical applications the analyte under consideration is often also present in tears, saliva or sweat, and the use of these matrices is still under developed, mainly because of sensitivity aspects. Application of more sensitive tags might be an option here. Although the restriction on the sample volume is a weakness (see earlier), it is also an opportunity, especially when only a limited amount of sample can be obtained, provided the target analyte is present in sufficient quantity to meet the sensitivity of the test.

Better reproducibility can be achieved by automation of the manufacturing process, automated addition of the sample and controlled drying time and read-out of the result. Preparation of the strips in a highly reproducible way using a controlled atmosphere (temperature, humidity, dust) is a recommendation. One approach is implemented by, e. g., Biodot, and is described in [94]. The use of an internal standard for higher reproducibility was mentioned [47, 48].

The lack of published applications in the field of environmental issues and plant pathology related items is remarkable. A few applications on the detection of plant viruses could be found [8, 18, 78]. However, many commercial kits are available nowadays.. For ecotoxicological items only one publication could be found [58], apart from the screening of some pesticides in food or feed (Table 3). LFAs can be of substantial interest in these fields.

Implementation of the microarray format as described in $[39,43]$ using an LFA and automated sample addition and read-out of the results might be an option for some applications.

Compared with biosensor technology (see later) the LFA technology can be brought to the market extremely quickly with a relatively small investment. At the time of writing, the investments in hardware and software for the consumer are also nil to minimal.
Threats

Nowadays the price of hardware and software of many test systems tends to decrease. This is, among others, due to miniaturisation of the hardware and reuse of software components. For some applications in, e.g., the emergency ward of hospitals, the physician's office, the milking parlour in the dairy industry, but not in the field, hardware that was out of the scope a few years ago might now provide an option for reliable, fast and low-cost tests. Although gas chromatography-mass spectrometry and liquid chromatography-mass spectrometry require trained personnel, applications use far more automation than a few years ago. Equipment miniaturised and integrated in the lab-on-a-chip format is already on the market (http:/www. c2v.nl)

Traditionally enzyme immunoassays are performed in centralised laboratories by manual intervention of trained technicians. Nowadays these tests can also be performed using highly sophisticated hardware in automated set-ups (ELISA robots). Two research groups designed an automated enzyme immunoassay set-up for off-laboratory tests on progesterone in bovine milk in the milking parlour for information on the reproductive status of dairy cows $[95,96]$.

The apoenzyme reactivation immunological system (ARIS) was rather popular at the end of the twentieth century [97]. This technique combines recognition of the analyte by its immunoglobulin ( $\mathrm{IgG}$ ) with signal enhancement by enzymatic processing of the label. Analyte-labelled flavin adenine dinucleotide can combine with apoglucose oxidase or can bind to analyte-specific IgG. When analyte is present in the sample, this will bind to the IgG and the analyte-labelled flavin adenine dinucleotide will reactivate the apoprotein to active holoenzyme. Addition of the substrate glucose generates $\mathrm{H}_{2} \mathrm{O}_{2}$, and horseradish peroxidase combined with a chromogen gives the signal that is linearly related to the amount of analyte in the sample. Many applications of the ARIS technique are already available in dry reagent format. These use an Ames Seralizer reflectometer that was specifically developed for this assay format [98-101]. Tests are provided for blood/ serum/plasma or saliva. However, recent applications, apart from the quantitation of trinitrotoluene in drinking water [102], were not mentioned.

According to the International Union of Pure and Applied Chemistry, a biosensor is "a self-contained integrated device, which is capable of providing specific quantitative or semi-quantitative analytical information using a biological recognition element (biochemical receptor) which is retained in direct spatial contact with a transduction element" [103]. The receptor acts upon a biochemical mechanism, while the transducer can be 
diverse in nature, e.g. a chemically modified electrode of electronic conducting, semiconducting or ionic conducting material, plasmon-generating, magnetoresistive or interferometer set-up, and is in direct contact with the biochemical receptor component. Some immunosensor formats are surface plasmon resonance, grating coupler, total internal reflectance fluorometry, magnetobiosensor and interferometer sensor. However, in some publications an LFA with optical transduction is called a "biosensor" [24, 26, 58, 79]. The magnetobiosensor, under development at Philips Research, may be a serious threat upon market introduction, because of its concept of full integration and disposable assay cartridges [104, 105]. However, from a cost calculation point of view, applications are primarily foreseen in the mid- and high-end markets. Introduction of the Young interferometer sensor as developed at the $\mathrm{MESA}^{+}$Institute at Twente University, The Netherlands, may be a serious threat for some applications [106].

Reduction of hardware costs for the microparticle immunoassay might give this technique a realistic option in resource-poor settings [107]. This can be an advantage for multianalyte testing. With use of, e.g., the Luminex ${ }^{\circledR}$ 100 technology, up to 100 different analytes can be tested in one run in high-throughput mode. At the time of writing, the price of the microparticles is a hurdle that has to be overcome. Other brands are available as well, sometimes for reduced costs. Especially when automated sample preparation is used this will reduce the assistance of trained personnel [108]. However, resource-poor settings often are devoid of electricity, which would hamper the use of such equipment.

A format that gets a lot of attention these days is the labon-a-chip format [109-112]. Apart from a much longer development time, the investments are considerable, as the whole microfluidic device has to be designed in advance and prepared using a cleanroom. In addition, the very small volumes that can be added to the microfluidic device also implicates that sufficient analyte should be present in such a small volume to be detectable.

With respect to the patent situation concerning lateral flow and lateral flow devices, the situation is very complicated. Several hundred patents have been filed and Inverness Medical Innovations has collected a number of important patents on lateral flow over the few last years by buying strategic companies. However, one of the most restricting patents on lateral flow is expiring, which would enable easier market access.

\section{Future perspectives}

For commercial applications it is important to improve on the reproducibility of the tests by automation of sample addition, recording and data processing.
The use of new labels such as quantum dots and the upconverting phosphor technology can improve the sensitivity, allowing for more dilution of the sample with less matrix interference or use of matrices with lower concentrations, such as tears or saliva $[9,113]$. Multiplexing techniques, such as labelling the immunoreagents with quantum dots [37], or upconverting phosphors with different optical properties is also an option for multianalyte testing [114, 115]. However, the "one-step" principle is lost in an application as described in [115] as several consecutive flows were applied. For some multianalyte applications the recognition elements were reported to be peptides [116] or a dedicated DNA sequence with hexapet tags [117]. Peptides can often be synthesised without difficulty, and can sidestep raising of specific antibodies. However, thorough investigation of sensitivity and selectivity will be necessary. Nucleic acid sequences of hexameric repeat tags (hexapet) as capture probes were reported for detection, and with use of this approach, discrimination between single nucleotide polymorphism sequences [117] was demonstrated.

Applications in the medical field in the Western world can take advantage of the development of integrating the LFA in a lab-on-a-chip design [113, 115]. Moreover, often a clinical laboratory is nearby providing additional facilities. However, costs will increase substantially. For real offlaboratory applications at point of care/need in resourcepoor settings, the best option is to use LFAs. Strips can be stored at ambient temperature for a prolonged time. However, good recognition elements must be available and visual qualitative on/off or semiquantitative results using, e.g., the bar code layout or a reflectometer, must be sufficient.

Acknowledgement The Dutch Technology Foundation (STW) supported the study; grant number GPG 06038.

Open Access This article is distributed under the terms of the Creative Commons Attribution Noncommercial License which permits any noncommercial use, distribution, and reproduction in any medium, provided the original author(s) and source are credited.

\section{References}

1. Leuvering JHW, Thal PJHM, van der Waart M, Schuurs AHWM (1980) J Immunoassay Immunochem 1:77-91

2. van Amerongen A, Wichers JH, Berendsen LBJM, Timmermans AJM, Keizer GD, van Doorn AWJ, Bantjes A, van Gelder WMJ (1993) J Biotechnol 30:185-195

3. Litman DJ, Hanlon TM, Ullman EF (1980) Anal Biochem 106:223-229

4. Pappas MG, Hajkowski R, Hockmeyer WT (1983) J Immunol Methods 64:205-214

5. Wang S, Quan Y, Lee N, Kennedy IR (2006) J Agric Food Chem 54:2491-2495

6. Koets M, Sander I, Bogdanovic J, Doekes G, van Amerongen A (2006) J Environ Monit 8:942-946 
7. Nielsen K, Yu WL, Kelly L, Bermudez R, Renteria T, Dajer A, Gutierrez E, Williams J, Algire J, de Eschaide ST (2008) J Immunoass Immunochem 29:10-18

8. Salomone A, Mongelli M, Roggero P, Boscia D (2004) J Plant Pathol 86:43-48

9. Zuiderwijk M, Tanke HJ, Niedbala RS, Corstjens PLAM (2003) Clin Biochem 36:401-403

10. Wang X, Li K, Shi D, Xiong N, Jin X, Yi J, Bi D (2007) J Agric Food Chem 55:2072-2078

11. Aldus CF, van Amerongen A, Ariens RMC, Peck MW, Wichers JH, Wyatt GM (2003) J Appl Microbiol 95:380-389

12. van Dam GJ, Wichers JH, Ferreira TMF, Ghati D, van Amerongen A, Deelder AM (2004) J Clin Microbiol 42:5458-5461

13. O'Keeffe M, Crabbe P, Salden M, Wichers J, van Peteghem C, Kohen F, Pieraccini G, Moneti G (2003) J Immunol Methods 278:117-126

14. Henderson K, Stewart J (2000) Reprod Fertil Dev 12:183-189

15. Kalogianni DP, Goura S, Aletras AJ, Christopoulos TK, Chanos MG, Christofidou M, Skoutelis A, Ioannou PC, Panagiotopoulos E (2007) Anal Biochem 361:169-175

16. Edwards KA, Baeumner AJ (2006) Anal Bioanal Chem 386:1335-1343

17. Al-Yousif Y, Anderson J, Chard-Bergstrom C, Kapil S (2002) Clin Diagn Lab Immunol 9:723-724

18. Kusano N, Hirashima K, Kuwahara M, Narahara K, Imamura T, Mimori T, Nakahira K, Torii K (2007) J Gen Plant Pathol 73:66-71

19. Zhang G-P, Guo J-Q, Wang X-N, Yang J-X, Yang Y-Y, Li Q-M, Li X-W, Deng R-G, Xiao Z-J, Yang J-F (2006) Vet Parasitol 137:286-293

20. Verheijen R, Stouten P, Cazemier G, Haasnoot W (1998) Analyst 123:2437-2441

21. Gussenhoven GC, van der Hoorn MA, Goris MG, Terpstra WJ, Hartskeerl RA, Mol BW, van Ingen CW, Smits HL (1997) J Clin Microbiol 35:92-97

22. Lou S, Patel C, Ching S, Gordon J (1993) Clin Chem 39:619-624

23. Lonnberg M, Carlsson J (2001) Anal Biochem 293:224-231

24. Zaytseva NV, Montagna RA, Lee EM, Baeumner AJ (2004) Anal Bioanal Chem 380:46-53

25. Baeumner AJ, Jones C, Wong C, Price A (2004) Anal Bioanal Chem 378:1587-1593

26. Baeumner AJ (2004) Food Technol 58:51-55

27. Ho JAA, Wauchope RD (2002) Anal Chem 74:1493-1496

28. Ho J-a, Zeng S-C, Tseng W-H, Lin Y-J, Chen C-h (2008) Anal Bioanal Chem 391:479-485

29. Ho JaA, Huang MR (2005) Anal Chem 77:3431-3436

30. Goldman ER, Clapp AR, Anderson GP, Uyeda HT, Mauro JM, Medintz IL, Mattoussi H (2004) Anal Chem 76:684-688

31. Corstjens P, Zuiderwijk M, Brink A, Li S, Feindt H, Niedbala RS, Tanke H (2001) Clin Chem 47:1885-1893

32. Snowden K, Hommel M (1991) J Immunol Methods 140:57-65

33. Oku Y, Kamiya K, Kamiya H, Shibahara Y, Ii T, Uesaka Y (2001) J Immunol Methods 258:73-84

34. Kolosova A, De Saeger S, Sibanda L, Verheijen R, Van Peteghem C (2007) Anal Bioanal Chem 389:2103-2107

35. Leung W, Chan CPY, Leung M, Lehmann K, Renneberg I, Lehmann M, Hempel A, Glatz JFC, Renneberg R (2005) Anal Lett 38:423-439

36. Zhang C, Zhang Y, Wang S (2006) J Agric Food Chem 54:25022507

37. Laitinen MPA, Sojakka KM, Vuento M (1996) Anal Biochem 243:279-282

38. Cho J-H, Paek S-H (2001) Biotechnol Bioeng 75:725-732

39. van Amerongen A, Koets M (2005) In: van Amerongen A, Barug D, Lauwaars M (eds) Rapid methods for biological and chemical contaminants in food and feed. Wageningen Academic Publishers, Wageningen, pp 105-126
40. Kozwich D, Johansen KA, Landau K, Roehl CA, Woronoff S, Roehl PA (2000) Appl Environ Microbiol 66:2711-2717

41. Connelly JT, Nugen SR, Borejsza-Wysocki W, Durst RA, Montagna RA, Baeumner AJ (2008) Anal Bioanal Chem 391:487-495

42. Fong WK, Modrusan Z, McNevin JP, Marostenmaki J, Zin B, Bekkaoui F (2000) J Clin Microbiol 38:2525-2529

43. Carter DJ, Cary RB (2007) Nucleic Acids Res 35:1-11

44. Clavijo E, Díaz R, Anguita Á, García A, Pinedo A, Smits HL (2003) Clin Diagn Lab Immunol 10:612-615

45. Doering WE, Piotti ME, Natan MJ, Freeman RG (2007) Adv Mater 19:3100-3108

46. Zhu Y, He W, Liang Y, Xu M, Yu C, Hua W, Chao G (2002) J Immunol Methods 266:1-5

47. Choi S, Choi EY, Kim DJ, Kim JH, Kim TS, Oh SW (2004) Clin Chim Acta 339:147-156

48. Ahn JS, Choi S, Jang SH, Chang HJ, Kim JH, Nahm KB, Oh SW, Choi EY (2003) Clin Chim Acta 332:51-59

49. Abitbol CL, Chandar J, Onder AM, Nwobi O, Montané B, Zilleruelo G (2006) Pediatr Nephrol 21:995-1002

50. Rundström G, Jonsson A, Mårtensson $\mathrm{O}$, Mendel-Hartvig I, Venge P (2007) Clin Chem 53:342-348

51. Fernandez-Sanchez C, McNeil CJ, Rawson K, Nilsson O, Leung HY, Gnanapragasam V (2005) J Immunol Methods 307:1-12

52. Wittfooth S, Qin Q-P, Lund J, Tierala I, Pulkki K, Takalo H, Pettersson K (2006) Clin Chem 52:1794-1801

53. Delmulle BS, DeSaeger SMDG, Sibanda L, Barna-Vetro I, van Peteghem CH (2005) J Agric Food Chem 53:3364-3368

54. Klewitz T, Gessler F, Beer H, Pflanz K, Scheper T (2006) Sens Actuators B Chem 113:582-589

55. Verheijen R, Osswald IK, Dietrich R, Haasnoot W (2000) Food Agric Immunol 12:31-40

56. Zhao J, He S-P, Liu W, Deng A-X, Nan T-G, Wang B-M, Zhai ZX, Li Z-H (2006) Food Agric Immunol 17:173-181

57. Huo T, Peng C, Xu C, Liu L (2006) Food Agric Immunol $17: 183-190$

58. Kim YM, Oh SW, Jeong SY, Pyo DJ, Choi EY (2003) Environ Sci Technol 37:1899-1904

59. Campbell K, Fodey T, Flint J, Danks C, Danaher M, O'Keeffe M, Kennedy DG, Elliott C (2007) J Agric Food Chem 55:2497-2503

60. Capps KL, McLaughlin EM, Murray AWA, Aldus CF, Wyatt GM, Peck MW, van Amerongen A, Ariëns RMC, Wichers JH, Baylis CL, Wareing DRA, Bolton FJ (2004) J AOAC Int 87:68-77

61. Biagini RE, Sammons DL, Smith JP, MacKenzie BA, Striley CAF, Snawder JE, Robertson SA, Quinn CP (2006) Clin Vaccine Immunol 13:541-546

62. Newgard JR, Rouse GC, McVicker JK (2002) J Agric Food Chem 50:3094-3097

63. Leung W, Chan CPY, Bosgoed F, Lehmann K, Renneberg I, Lehmann M, Renneberg R (2003) J Immunol Methods 281:109 118

64. Bogdanovic J, Koets M, Sander I, Wouters I, Meijster T, Heederik D, van Amerongen A, Doekes G (2006) J Allergy Clin Immunol 118:1157-1163

65. van Amerongen A, van Loon D, Berendsen LBJM, Wichers JH (1994) Clin Chim Acta 229:67-75

66. Tanaka R, Yuhi T, Nagatani N, Endo T, Kerman K, Takamura Y, Tamiya E (2006) Anal Bioanal Chem 385:1414-1420

67. Laitinen MPA, Vuento M (1996) Acta Chem Scand 50:141-145

68. Laitinen MPA, Vuento M (1996) Biosens Bioelectron 11:12071214

69. Soo P-C, Horng Y-T, Hsueh P-R, Shen B-J, Wang J-Y, Tu H-H, Wei J-R, Hsieh S-C, Huang C-C, Lai H-C (2006) J Microbiol Methods 66:440-448

70. Seal J, Braven H, Wallace P (2006) IVD Technol 11:41-54

71. Paek S-H, Lee S-H, Cho J-H, Kim Y-S (2000) Methods 22:53-60 
72. Jin S, Chang ZY, Ming X, Min CL, Wei H, Sheng LY, Hong GX (2005) Clin Diagn Lab Immunol 12:198-201

73. Buechler KF, Moi S, Noar B, McGrath D, Villela J, Clancy M, Shenhav A, Colleymore A, Valkirs G, Lee T (1992) Clin Chem 38:1678-1684

74. Henderson K, Stewart J (2002) J Immunol Methods 270:77-84

75. Zhang GP, Wang XN, Yang JF, Yang YY, Xing GX, Li QM, Zhao D, Chai SJ, Guo JQ (2006) J Immunol Methods 312:27-33

76. Greenwald R, Esfandiari J, Lesellier S, Houghton R, Pollock J, Aagaard C, Andersen P, Hewinson RG, Chambers M, Lyashchenko K (2003) Diagn Microbiol Infect Dis 46:197-203

77. Aveyard J, Mehrabi M, Cossins A, Braven H, Wilson R (2007) Chem Commun 2007:4251-4253

78. Danks C, Barker I (2000) EPPO Bull 30:421-426

79. Yan Z, Zhou L, Zhao Y, Wang J, Huang L, Hu K, Liu H, Wang H, Guo Z, Song Y, Huang H, Yang R (2006) Sens Actuators B Chem 119:656-663

80. Lee KS, Kim T-H, Shin M-C, Lee W-Y, Park J-K (1999) Anal Chim Acta 380:17-26

81. Bartolini M, Andrisano V, Wainer IW (2003) J Chromatogr A 987:331-340

82. Wittmann C, Bilitewski U, Giersch T, Kettling U, Schmid RD (1996) Analyst 121:863-869

83. Birnbaum S, Udén C, Magnusson CGM, Nilsson S (1992) Anal Biochem 206:168-171

84. Sananikone K, Delwiche MJ, BonDurant RH, Munro CJ (2002) Trans ASAE 47:1357-1365

85. Pal A, Dhar TK (2004) Anal Chem 76:98-104

86. Muhammad-Tahir Z, Alocilja EC (2003) Biosens Bioelectron 18:813-819

87. Sippy N, Luxton R, Lewis RJ, Cowell DC (2003) Biosens Bioelectron 18:741-749

88. Inoue K, Ferrante P, Hirano Y, Yasukawa T, Shiku H, Matsue T (2007) Talanta 73:886-892

89. Horton JK, Swinburne S, O’Sullivan MJ (1991) J Immunol Methods 140:131-134

90. Shyu R-H, Shyu H-F, Liu H-W, Tang S-S (2002) Toxicon 40:255-258

91. Zhou P, Lu Y, Zhu J, Hong J, Li B, Zhou J, Gong D, Montoya A (2004) J Agric Food Chem 52:4355-4359

92. Oh SW, Moon JD, Park SY, Jang HJ, Kim JH, Nahm KB, Choi EY (2005) Clin Chim Acta 356:172-177

93. Gabaldón JA, Cascales JM, Morias S, Maquieira A, Puchades R (2003) Food Addit Contam 20:707-715

94. Tisone TC, Citeau H, McIntosh B (2007) IVD Technol 13:37-41

95. Xu YF, Velasco-Garcia M, Mottram TT (2005) Biosens Bioelectron 20:2061-2070
96. Delwiche M, Tang X, BonDurant R, Munro C (2001) Trans ASAE 44:1997-2002

97. Kasahara Y, Ashihara Y (1997) Clin Chim Acta 267:87-102

98. Miles MV, Tennison MB, Greenwood RS, Benoit SE, Thorn MD, Messenheimer JA, Ehle AL (1990) Ther Drug Monit 12:501-510

99. Rupchock P, Sommer R, Greenquist A, Tyhach R, Walter B, Zipp A (1985) Clin Chem 31:737-740

100. Sommer R, Clayborn J, Thompson S, Greenquist A (1988) Ther Drug Monit 10:197-204

101. Thompson SG, Boguslaski RC (1987) J Clin Lab Anal 1:293-299

102. Heiss C, Weller MG, Niessner R (1999) Anal Chim Acta 396:309-316

103. Thévenot DR, Toth K, Durst RA, Wilson GS (1999) Pure Appl Chem 71:2333-2348

104. Megens M, Prins M (2005) J Magn Magn Mater 293:702-708

105. de Boer BM, Kahlman JAHM, Jansen TPGH, Duric H, Veen J (2007) Biosens Bioelectron 22:2366-2370

106. Ymeti A, Greve J, Lambeck PV, Wink T, vanHovell SWFM, Beumer TAM, Wijn RR, Heideman RG, Subramaniam V, Kanger JS (2007) Nano Lett 7:394-397

107. Jani IV, Janossy G, Brown DWG, Mandy F (2002) Lancet Infect Dis 2:243-250

108. Hindson BJ, Brown SB, Marshall GD, McBride MT, Makarewicz AJ, Gutierrez DM, Wolcott DK, Metz TR, Madabhushi RS, Dzenitis JM, Colston BW (2004) Anal Chem 76:3492-3497

109. Kim J-E, Cho J-H, Paek S-H (2005) Anal Chem 77:7901-7907

110. Yakovleva J, Davidsson R, Lobanova A, Bengtsson M, Eremin S, Laurell T, Emneus J (2002) Anal Chem 74:2994-3004

111. Tüdós AJ, Besselink GAJ, Schasfoort RBM (2001) Lab Chip 1:83-95

112. Situma C, Hashimoto M, Soper SA (2006) Biomol Eng 23:213231

113. Abrams WR, Barber CA, McCann K, Tong G, Chen Z, Mauk MG, Wang J, Volkov A, Bourdelle P, Corstjens PLAM, Zuiderwijk M, Kardos K, Li S, Tanke HJ, Niedbala RS, Malamud D, Bau H (2007) Ann N Y Acad Sci 1098:375-388

114. Niedbala RS, Feindt H, Kardos K, Vail T, Burton J, Bielska B, Li S, Milunic D, Bourdelle P, Vallejo R (2001) Anal Biochem 293:22-30

115. Corstjens PLAM, Chen Z, Zuiderwijk M, Bau HH, Abrams WR, Malamud D, Niedbala RS, Tanke HJ (2007) Ann N Y Acad Sci 1098:437-445

116. Kulagina NV, Shaffer KM, Ligler FS, Taitt CR (2007) Sensor Actuators B Chem 121:150-157

117. Barnard R, George C, Jacobs K, Wu ACK, Nagasaki TK, Shan J, Greenwood K, Kachab E (2005) Point Care 4:108-118 